Review

\title{
Biofilm and Small Colony Variants-An Update on Staphylococcus aureus Strategies toward Drug Resistance
}

\author{
Henan Guo, Yucui Tong, Junhao Cheng (D), Zaheer Abbas $\mathbb{D}$, Zhongxuan Li ${ }^{\dagger}$, Junyong Wang, Yichen Zhou, \\ Dayong Si and Rijun Zhang *
}

Citation: Guo, H.; Tong, Y.; Cheng, J.; Abbas, Z.; Li, Z.; Wang, J.; Zhou, Y.; Si, D.; Zhang, R. Biofilm and Small Colony Variants-An Update on Staphylococcus aureus Strategies toward Drug Resistance. Int. J. Mol. Sci. 2022, 23, 1241. https://doi.org/ $10.3390 /$ ijms 23031241

Academic Editor: Cidália Pina-Vaz

Received: 20 December 2021

Accepted: 20 January 2022

Published: 22 January 2022

Publisher's Note: MDPI stays neutral with regard to jurisdictional claims in published maps and institutional affiliations.

Copyright: (C) 2022 by the authors. Licensee MDPI, Basel, Switzerland. This article is an open access article distributed under the terms and conditions of the Creative Commons Attribution (CC BY) license (https:// creativecommons.org/licenses/by/ $4.0 /)$.
Laboratory of Feed Biotechnology, State Key Laboratory of Animal Nutrition, College of Animal Science and Technology, China Agricultural University, Beijing 100193, China; ghn_657@cau.edu.cn (H.G.); 15956910334@163.com (Y.T.); chengjunhao@cau.edu.cn (J.C.); Zaheerabbas113@yahoo.com (Z.A.); Lee_zx20@yeah.net (Z.L.); wangjy9722@163.com (J.W.); redhoh@163.com (Y.Z.); dayong@cau.edu.cn (D.S.)

* Correspondence: zhangrj621@126.com; Tel.: +86-10-6273-1208

+ Current Affiliation: College of Bioengineering, Sichuan University of Science \& Engineering, Zigong 643000, China.

\begin{abstract}
Recently, the drawbacks arising from the overuse of antibiotics have drawn growing public attention. Among them, drug-resistance (DR) and even multidrug-resistance (MDR) pose significant challenges in clinical practice. As a representative of a DR or MDR pathogen, Staphylococcus aureus can cause diversity of infections related to different organs, and can survive or adapt to the diverse hostile environments by switching into other phenotypes, including biofilm and small colony variants (SCVs), with altered physiologic or metabolic characteristics. In this review, we briefly describe the development of the DR/MDR as well as the classical mechanisms (accumulation of the resistant genes). Moreover, we use multidimensional scaling analysis to evaluate the MDR relevant hotspots in the recent published reports. Furthermore, we mainly focus on the possible non-classical resistance mechanisms triggered by the two important alternative phenotypes of the S. aureus, biofilm and SCVs, which are fundamentally caused by the different global regulation of the S. aureus population, such as the main quorum-sensing (QS) and agr system and its coordinated regulated factors, such as the SarA family proteins and the alternative sigma factor $\sigma \mathrm{B}$ (SigB). Both the biofilm and the SCVs are able to escape from the host immune response, and resist the therapeutic effects of antibiotics through the physical or the biological barriers, and become less sensitive to some antibiotics by the dormant state with the limited metabolisms.
\end{abstract}

Keywords: drug-resistance; multidrug-resistance; Staphylococcus aureus; biofilm; small colony variants; global regulation; resistant mechanisms

\section{Introduction}

In the past decades, antibiotics have played a significant role in reducing the risks involved in childbirth, injuries, and intrusive medical procedures [1,2]. However, abuse or overuse of antibiotics in the circumstances of experimental studies and clinical treatments poses a severe threat to public health by acquiring drug-resistance (DR) and multidrugresistance (MDR) of the pathogens [3,4]. It is of great concern that if the growing resistance to antibiotics continues, the global economies will suffer a sharp loss of USD 100 trillion by 2050 [5].

Among the DR/MDR pathogens, Staphylococcus aureus is an all-powerful pathogen that can cause acute, persistent, and chronic infections [6]. The failure of antibiotics in the clinical treatment is a complex outcome of the accumulation of resistance-relevant genes and the internal tolerant nature of the flexible phenotype changes of $S$. aureus, including biofilm formation and small colony variants (SCVs) [7]. Phenotypic change is a part of the normal growth cycle of the bacteria [8], and acts as an insurance approach to avoid harmful environments [9]. With the help of these alternative phenotypes, S. aureus can survive 
and adapt to the corresponding environments, and further invade the host body [7]. It is known that the development of these novel phenotypes has been involved in chronicity and relapse in S. aureus-relevant infections [10], such as chronic osteomyelitis [11,12], chronic rhinosinusitis $[13,14]$, soft tissue infections $[15,16]$, endocarditis $[17,18]$, sepsis $[19,20]$, and medical device-related infections [21]. Infections caused by either biofilm or SCVs have certain common features, including the failure of host defenses arising from their dormant state, and the inherent tolerance of antibiotics [7,22]. Behaviors of $S$. aureus population are generally controlled by a global regulation system, such as the quorum-sensing (QS) system, which is concerned as a population density-dependent and environment-dependent regulatory pathway to ensure intercellular communication [23]. Therefore, some special regulations allow alternative lifestyles, such as biofilm and SCVs, to form the individual physiology, metabolic, and pathogenic characteristics to adapt to the altered living environments. In turn, those special features enable biofilm and SCVs to combat the host immune effect and even resist the therapeutic effect of the common antibiotics.

In this review, we focus on the development of DR/MDR and the classical resistant mechanisms associated with the accumulation of the resistance genes and analyze the hotspots of the recently published reports with keywords "MDR/multidrug-resistance/ multidrug-resistant" by multidimensional scaling analysis. Furthermore, this review seeks to give a comprehensive overview of the formation, the critical global regulatory pathways, and the possible drug-resistance mechanisms of the $S$. aureus alternative phenotypes, biofilm and SCVs.

\section{The Development of DR or MDR}

With the discovery of antibiotics, humans once got rid of some infections caused by pathogens. However, during the past decades, the armed pathogen has rendered lots of antibiotics insensitive and ineffective, even vancomycin, the last defense against multi-resistant bacteria, cannot avoid the same fate [24]. During the pathogens' endless coevolutionary process with humans, antibiotics arguably become the most powerful selective pressure on drug-resistance [25]. For instance, the history of $S$. aureus drug resistance is listed in Table 1. As shown, the rise of new antibiotics could figure out the current epidemics around the world caused by S. aureus. However, it is also an inevitable trend that the drug resistance spectrum of $S$. aureus can be widened.

Table 1. Different drug-resistance stages of S. aureus.

\begin{tabular}{|c|c|c|c|c|c|}
\hline Resistant Stage & Occurrence Time & Mechanism & Drug Resistance & Typical Strain & Reference \\
\hline $\begin{array}{l}\text { Penicillin-resistant } \\
\text { strains }\end{array}$ & In the mid- $1940 \mathrm{~s}$ & $\begin{array}{l}\text { Plasmid-encoded } \\
\text { penicillinase } \\
\text { hydrolysing the } \\
\beta \text {-lactam ring of } \\
\text { penicillin }\end{array}$ & Penicillin & $\begin{array}{c}\text { Phage type } 80 / 81 \\
\text { S. aureus }\end{array}$ & {$[26,27]$} \\
\hline $\begin{array}{c}\text { Methicillin-resistant } S . \\
\text { aureus (MRSA) }\end{array}$ & 1961 & $\begin{array}{l}\text { Gene mec } A \text { and } \\
\text { mecC encoding the } \\
\text { low-affinity } \\
\text { penicillin-binding } \\
\text { protein PBP2A or } \\
\text { PBP2A } A_{\text {LGA }}\end{array}$ & $\begin{array}{c}\text { Entire } \beta \text {-lactam } \\
\text { class of antibiotics }\end{array}$ & MRSA COMRSAL & {$[28,29]$} \\
\hline $\begin{array}{l}\text { Vancomycin-resistant } \\
\text { S. aureus (VRSA) }\end{array}$ & $\begin{array}{l}\text { At the end of the } \\
\text { 20th century }\end{array}$ & $\begin{array}{l}\text { Mediated by vanA } \\
\text { gene cluster }\end{array}$ & Vancomycin & $\mathrm{N} / \mathrm{A}$ & {$[24,30]$} \\
\hline
\end{tabular}

Pathogens can develop resistance to most effective antibiotics in clinical treatment, and further, lead to urgent issues to the global human health [31]. It is accepted that the mechanisms of drug resistance are diverse and complicated. The majority of the classical drug resistance mechanisms are shown in Figure 1 [31]. These resistance mechanisms arise from pathogen chromogene mutations and the acquisition of resistance genes from other strains during the horizontal gene transfer (HGT) process [32]. 


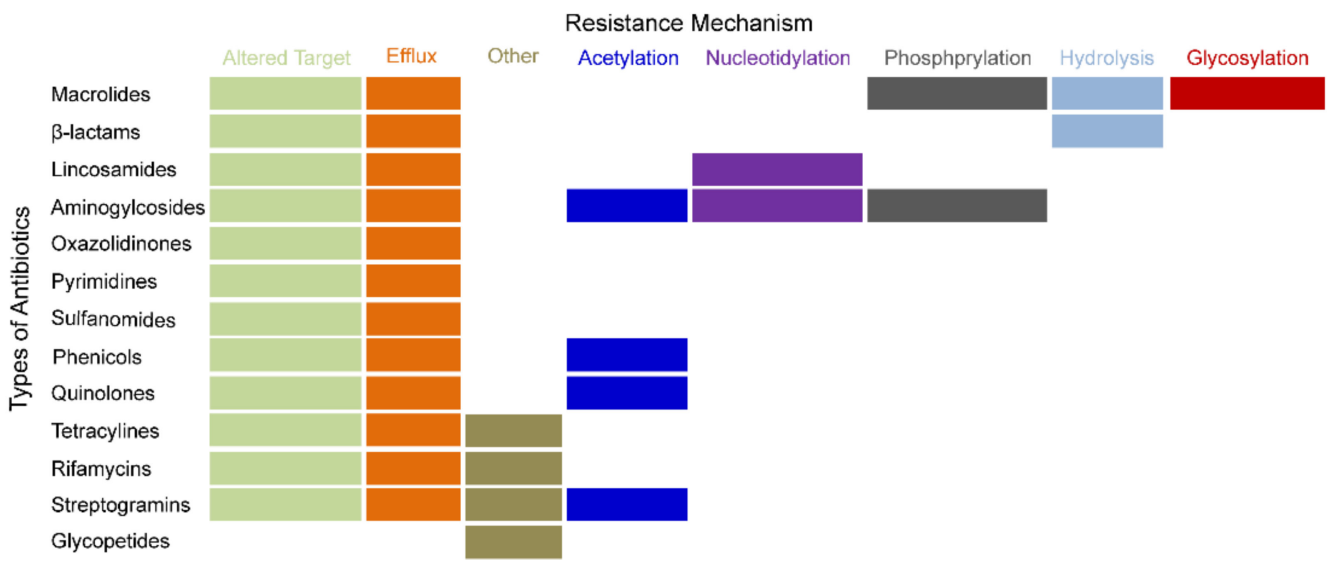

Figure 1. Classical drug-resistant mechanisms of common antibiotics. This figure was modified based on the Figure 1 of Dunn, et al. [31]. Labels in different colors stand for various drug-resistant mechanisms.

Apart from the defects in the clinical treatment, it also has been reported that antibiotics used in veterinary practices are positively associated with resistance genes in both pigs and poultry [33]. In addition, the microbes of livestock have been proven to disturb human health by delivery of resistant bacteria and genes HGT [34]. Last but not least, the overuse of antibiotics can also result in environmental pollution, reflected as the ubiquitous detectable rate of antibiotics in natural ecosystems, especially fresh waters, which might aggravate drug resistance and destroy the food chain by toxicity in the waters [35].

\section{The Hotspots of MDR Relevant Recent Studies}

The ever-increasing population of MDR pathogens has become a tough challenge menacing global public health care systems [36]. MDR is known as microbial resistance against at least two antimicrobial agents that used to be sanitary [37]. Antibiotic-resistant infections are capable of inducing morbidity and raising mortality [38-40]. The majority of nosocomial infections are caused by the ESKAPE pathogens, including Enterococcus faecium, S. aureus, Klebsiella pneumoniae, Acinetobacter baumannii, Pseudomonas aeruginosa, and Enterobacter species, most of which possess multidrug-resistance [3]. In particular, the rise of super-bacteria has been observed for a while, which sounds another alarm for global health [41].

Recently, studies on MDR have been mounting, containing several aspects. From January to June 2021, 2666 articles with the keywords "MDR/multidrug-resistance/multidrugresistant" (excluding cancer-related reports) have been included in the Web of Science core collection. SATI software was used to analyze and evaluate hotspots, frequencies, and relationships of the targeted research [42]. Based on the results of SATI, multidimensional scaling analysis can discover the topic distribution of the target studies by measuring the distance between different keywords [42]. The distances of dots indicate the relationship of each keyword, namely, the closer the distance, the stronger the correlation. Figure 2 demonstrates the results of the multidimensional scale analysis of the top 25 keywords in the MDR-related studies. The keywords could be classified into several classes: DR/MDR pathogens (P. aeruginosa, Enterobacteriaceae, E. coli, A. baumannii, Salmonella, S. aureus, MRSA, M. tuberculosis, Klebsiella pneumoniae, C. auris, MDR-TB, and P. falciparum); resistant antibiotic or factors [colistin, extended-spectrum $\beta$-lactamases (ESBL), and mcr-1]; MDR pathogen-related characteristics (virulence and biofilm); new antibiotic alternatives (AMPs and nanomaterial); and a useful drug-resistance gene detection method whole-genome sequencing. We can conclude that, for the past 6 months, over 2000 articles related to different DR/MDR pathogens have been reported, proving again that MDR has become a crucial problem that needs to be handled. As shown in Figure 2, S. aureus was the closest one from MDR among all reported MDR pathogens, which suggested that many studies 
have concentrated on the connection between S. aureus and MDR. In this review, we will focus on the unconventional possible resistance mechanisms of S. aureus.

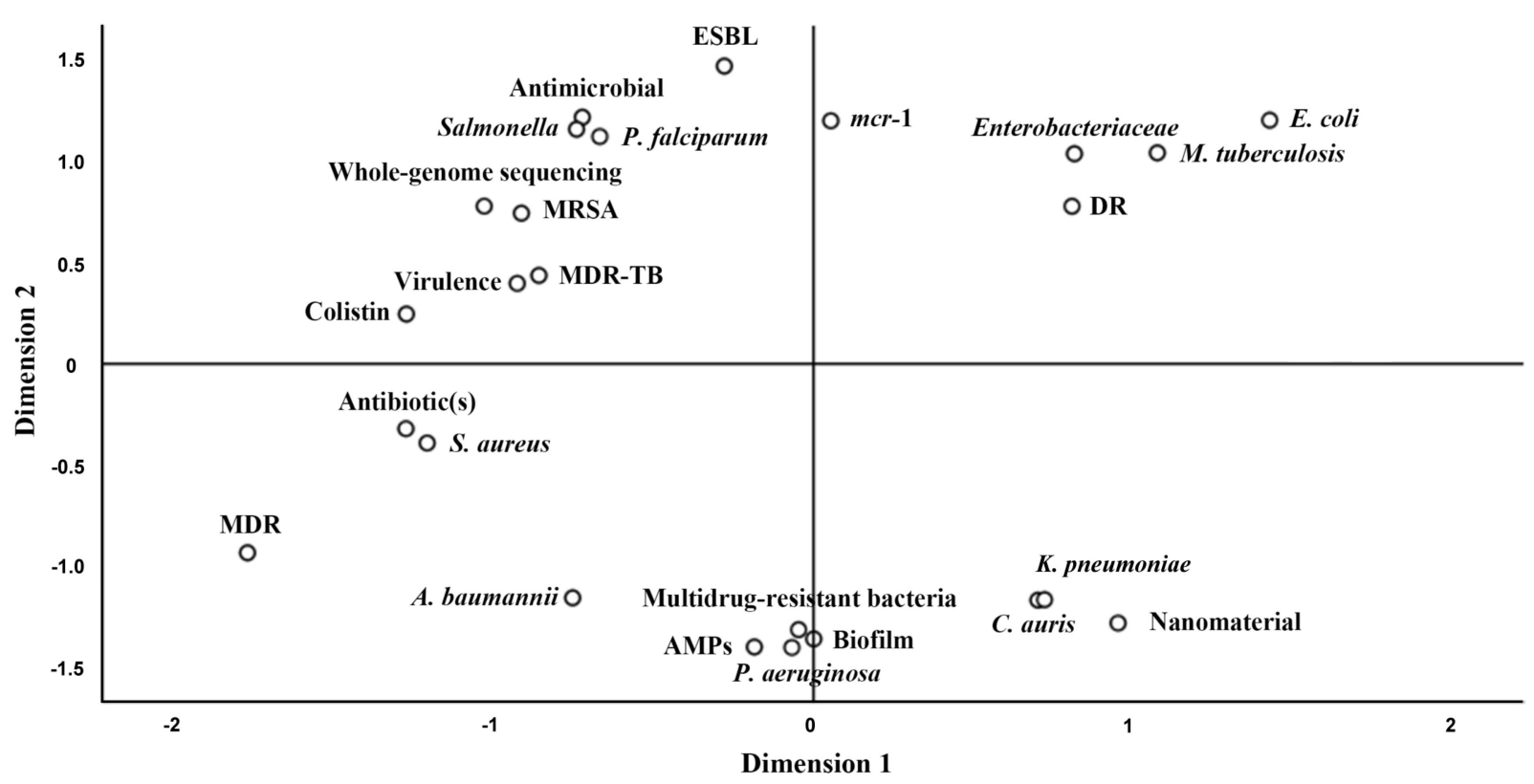

Figure 2. Multidimensional scaling (MDS) of MDR-related reports in the Web of Science core collection.

\section{Alternative Typical Phenotypic Switches of S. aureus}

S. aureus is an all-powerful pathogen connected to various clinical syndromes, ranging from acute sepsis to more persistent chronic infections related to endocardium, lung, marrow, skin, and soft tissues [6]. These infections can be difficult to cure due to the increased tolerance of $S$. aureus to antibiotics [43]. Consequently, S. aureus is also concerning as a human pathogen responsible for high morbidity and mortality worldwide [6,44].

$S$. aureus has been proven to to be invading and surviving in both professional and non-professional phagocytes $[45,46]$. Then, $S$. aureus may undergo three distinct fates: $S$. aureus escapes from the phagosome, proliferates inside the host cells that tend to be finally killed by the bacteria; $S$. aureus is killed by the host defense reactions; and it remains alive intracellularly without being eliminated [45].

Intracellular localization can protect $S$. aureus from the host immune system and treatment of antibiotics [47]. Unlike the classical resistance mechanisms by the acquisition of new virulence genes, the phenotypes existing within a genetically clonal population confer tolerance to antibiotics, which are defined as alternative lifestyles with limited or no growth, but are survival cells $[43,48,49]$. Although the mechanisms might be distinct, these alternative lifestyles tend to form dormant subpopulations to improve adaptation in unfavorable conditions [43], which are difficult to clear up by the host immune system or other therapeutic methods, and can revert to their original parental and active type at the right time $[50,51]$. It is known that small colony variants (SCVs) and biofilm are two typical phenotypic switches of S. aureus [43].

\subsection{An Introduction of Biofilm Phenotype}

\subsubsection{Formation of $S$. aureus Biofilm}

It is estimated that over $60 \%$ of treated bacterial infections arise from biofilm in developed countries [52]. Implantable medical devices have become an important part of modern healthcare, but they are also facing the challenge of biofilm-relevant infections caused by surface-adhering bacteria, especially $S$. aureus [53].

Biofilm is a biotic or abiotic surface-dependent multicellular lifestyle that embeds bacteria in its extracellular matrix composed of extracellular polymeric substance (EPS), 
proteins, and extracellular DNA [54]. Usually, the formation of biofilm consists of the following stages: attachment of planktonic cells to a substratum surface; colonization, fertilization, and biofilm mature; biofilm maturation; and biofilm dispersal [55], as shown in [54]. As soon as the biofilm grows into a mature three-dimensional structure, the community of the biofilm disassembles and releases the planktonic cells, which are ready to repeat the process to form a new biofilm [54]. Generally, the growing cells within biofilms are classically divided into four metabolic states: aerobic (located in the outer layers with sufficient oxygen and nutrients), fermentative (located in the inner layers with lack of oxygen and nutrients), dormant (located in anoxic layer with slow growth and inactive metabolism) and dead, among which the dormant cells dominate and have potential to eventually become persister cells [56]. S. aureus biofilm protects the cells from hostile conditions, including extreme temperature, limitations of nutrients and dehydration, and even antibacterial drugs [52,57].

The formation and the bioactivities of biofilm are determined by the fundamental components. In terms of the composition of biofilm, the majority of EPS components within S. aureus biofilm is the polysaccharide intercellular adhesin (PIA) [58], which plays an important role in several aspects, including colonization, biofilm generation and biofilmassociated infections, immune evasion, and resistance to antimicrobials and phagocytosis [59]. What is more, S. aureus EPS also connects to the following proteins with different effects: accumulation-associated proteins (Aap) interact with PIA to facilitate the maturation of biofilm [58]; the surface-binding proteins, Spa and SasG, are related to surface attachment and infections [60]; the fibronectin-binding proteins, FnbA and FnbB, can afford the pathogen the ability to attach to cellular integrins and further trigger the internalization into the host cells [61]; and the cell wall-anchored (CWA) proteins facilitate the adhesion among EPS, the membrane of the host cell, and the CWA proteins on adjacent cells, thus promoting the accumulation of biofilm [62]. Furthermore, it is accepted that amyloid fibers can provide a scaffold for biofilm to form a basis of matrix and maintain its structural stability $[63,64]$. Except for the above components, eDNA has also been proven to be crucial in the formation of biofilm by facilitating the irreversible attachment, inducing the HGT progress, maintaining the integrity of biofilm, increasing the tolerance of drugs, and guaranteeing the evasion from the host's innate immune system [65].

\subsubsection{Global Regulation of S. aureus Biofilm Formation}

The development of biofilm is a population behavior that is tightly controlled by a complex global regulatory system. One of the main regulatory systems is the quorumsensing (QS) system [66]. The QS system is responsible for intercellular communication of bacteria by modulating the population behavior in a density-dependent manner [67]. The agr system, the most essential part of the QS system of S. aureus, regulates the expression of about 150 genes encoding adhesins and virulence factors as well as the accumulation of extracellular auto-inducing peptides (AIPs) to control the cell population density [68]. The multifunctional agr system consists of two different operons, RNAII and RNAIII, activated by the promoters $\mathrm{P} 2$ and $\mathrm{P} 3$, respectively [69].

The operon RNAII contains agr BDCA genes, encoding AgrBDCA proteins, respectively [70]. AgrD, the precursor of AIP, is produced and exported on the plasma membrane with the aid of AgrB and Spsb (signal peptidase IB) [70]. Once AIP reaches the threshold concentration, it will bind to the receptor of the membrane-bound histidine kinase AgrC, followed by the activation of the AgrC kinase [71]. Finally, the response regulator AgrA is phosphorylated by AgrC to initiate the signaling cascade process, which in turn produces a positive feedback loop on P2 and P3 promoters [70]. RNAIII, an important effector of the agr system, can upregulate genes encoding exoproteins including toxins, haemolysins and exoproteases; meanwhile, it is also responsible for the downregulation of several genes encoding surface-related adhesins, such as fibronectin-binding proteins and serine-aspartate repeat family proteins [71,72] Additionally, the phenol-soluble modulin (PSMs) family and 
matrix-degrading enzymes in S. aureus are directly upregulated by AgrA $[71,73,74]$, which are known to facilitate the maturation and disassembly of biofilm [75].

Except for the agr system, there exist several important regulatory factors to participate in the formation of biofilm, which can interact or cooperate with the agr system in the global regulation of S. aureus, as shown in Figure 3 (modified based on Figure 2 of Schilcher et al. [54]).

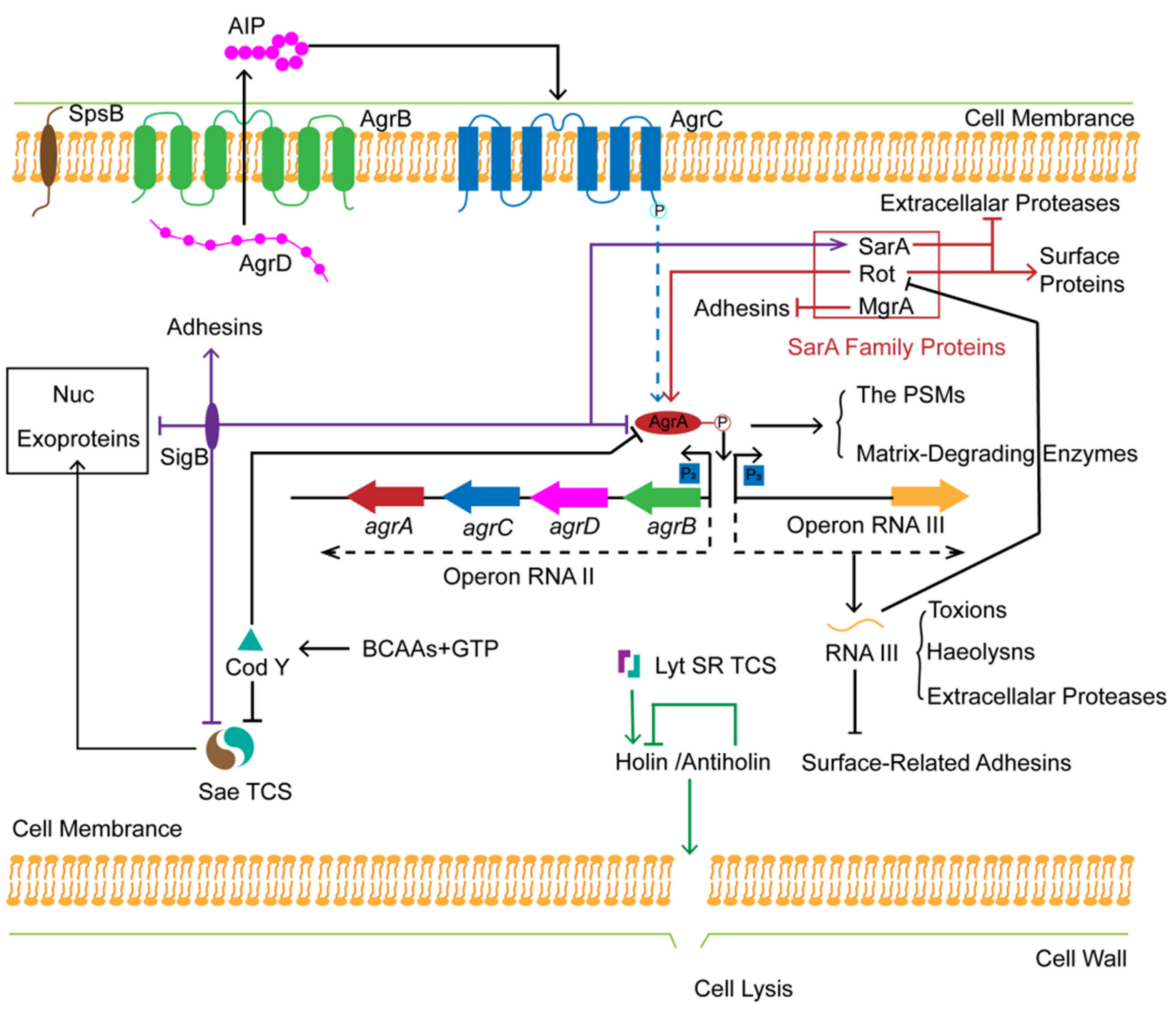

Figure 3. Global regulation of S. aureus biofilm formation. This figure was modified based on Figure 2 of Schilcher et al. [54].

- The Sae and the LytSR Two-Component Systems

Among complex regulators of the $S$. aureus global regulation system, there exist several two-component systems, such as the $S$. aureus exprotein expression (Sae) two-component system (TCS) and LytSR TCS. Namely, the complete function of the system is controlled by two different but related elements.

The S. aureus exprotein expression (Sae) two-component system (TCS) contains a sensor histidine kinase SaeS and a response regulator SaeR [76]. The former component controls the expression of several exoproteins during biofilm formation, such as a-hemolysin (Hla), FnbA, FnbB, and the extracellular thermonuclease Nuc (cleaving the eDNA contained in the matrix) [77-81].

Cell death and lysis of $S$. aureus are controlled by the holin/antiholin system [82] encoded by cidA and IraA, respectively $[83,84]$. The holin can improve extracellular murein hydrolase activity resulting in cell lysis, which is antagonized by antiholin $[84,85]$. The biosynthesis of holin/antiholin is tightly controlled by the LytSR TCS [86].

\section{- SarA Family Proteins}

The formation of biofilm is also controlled by the Staphylococcal accessory regulator (SarA) family proteins. Herein, we briefly describe three members of the SarA family, SarA, Rot, and MgrA. SarA, a general transcriptional factor, can directly upregulate the expression of exoproteins [87] and the agr system [88], whereas it can downregulate the extracellular proteases during the biofilm formation [89]. Rot can induce the expression 
of surface proteins and repress the production of extracellular enzymes [90-92], which is suppressed by the effector RNAIII of the agr system [93,94]. MgrA acts as a negative regulator of biofilm formation by repressing the production of adhesins [95].

- $\quad$ Alternative Sigma Factor $\sigma^{\mathrm{B}}$ (SigB)

Biofilm formation is a natural survival strategy for S. aureus to adapt to hostile environments, which means that the pathogen population needs to respond to the stress quickly. Due to the regulation of stress-relevant genes by the induction of the transcriptional alternative sigma factor $\sigma^{\mathrm{B}}(\mathrm{SigB})$, it is possible for $S$. aureus to survive in extreme conditions [96]. Moreover, SigB can promote the initial stage of biofilm formation by increasing the biosynthesis of adhesins and can repress the dispersal of the mature biofilm by decreasing the transcriptional level of the thermonuclease Nuc and proteases [97-101]. What is more, SigB can indirectly regulate the biofilm formation through influencing the other regulatory systems, for instance, by inhibiting the activity of RNAIII and SaeRS TCS, and upregulating the SarA expression based on the corresponding environments [102-104].

- The Transcriptional Repressor CodY

Usually, biofilm formation is controlled by the nutritional availability and the metabolic state of the bacteria [54]. S. aureus can fit in the stationary growth phase and starvation by modulating over 100 genes expression related to primary metabolism, transport, and virulence via a DNA-binding factor, CodY, which is triggered by a nutritional sufficient threshold of branched-chain amino acids (BCAAs) and GTP [105-107]. Besides, depressed CodY can induce the increased level of thermonuclease Nuc by the Sae TCS, resulting in the cascading regulation of toxins and the generation of factors [108]. What is more, CodY is also essential in the early stage of biofilm formation by strongly repressing the agr system [109].

\subsubsection{Drug-Resistance Mechanisms Induced by Biofilm of S. aureus}

Under global regulation, the biofilm of $S$. aureus forms, which empowers the microbial population to increase the tolerance of the antibiotics. As biofilm effectively shields bacteria from harsh host environments, it is complicated to explain the drug resistance mechanisms of biofilm [53]. Previous studies revealed several reasons for the drug resistance of biofilm, including its physical barrier, physiology states, oxygen availability, and genome adaptability [110-112]. One of the resistance mechanisms is related to the structural characteristics of the biofilm matrix itself. During the process of infection, the biofilms provide a strong safeguard from handicaps, including the host immune response and antibiotic therapy. As biofilm acts as a strong physical barrier to conceal pathogen-associated molecular patterns (PAMPs), those pathogens are capable of resisting the host immune response for a long time $[44,62,113,114]$. Moreover, biofilm can also protect the invading bacteria from the immune system of the host by disrupting the activation of phagocytes and the complement system $[115,116]$. Similarly, due to the limited diffusion and repulsion of antibiotics under such a complicated matrix, it is hard for drugs to get access to the target, thus allowing the generation of drug resistance [117-119]. It has been reported that, compared to the planktonic cells, bacteria within the biofilm can increase the tolerance against the conventional antibiotics by about 1,000-fold [58,120,121]. Furthermore, the physiological state of the bacteria within biofilm also contributes to the altered tolerance of antibiotics. Due to the lack of nutrients or oxygen, bacteria within the biofilm, particularly those deep within the matrix, tend to turn into a dormant state or persister cells, of which the limited growth can reduce the efficacy of antibiotics targeting the active cell processes [122-124]. Dormant cells grow slowly with a limited metabolism state, resulting in reduced intracellular ATP concentration, which makes bacteria less sensitive to antibiotics [125-127]. What is more, suffering from several times of treatment by antibiotics, cells in dormancy state remain alive and ready to continue the formation of biofilm [122]. Last but not least, cells in biofilm undergo a higher rate of resistance-relevant mutation than planktonic cells [128]. 


\subsection{An Introduction of Biofilm Phenotype}

\subsubsection{Formation of SCVs}

S. aureus SCVs first attracted public attention due to the association with chronic and recurrent infections in 1995 [129]. Recently, SCVs have been proven to be an essential cause for infections in different organs [130-132]. It was reported that S. aureus SCVs were found in $29 \%$ of osteomyelitis clinical cases [133] and 17-46\% of chronic cystic fibrosis cases [134-136]. In particular, prolonged survival of $S$. aureus within the host cells has been associated with an increasing percentage of SCV sub-population [7]. SCVs, with the small colony and variable phenotypic stability, have been defined as a type of slow-growing bacterial sub-population formed under a certain selective pressure, including extreme $\mathrm{pH}$, cold stress, nutrition limitation, exposure to antibiotics or disinfectants, and location or survival in the host cells [137-139] (Figure 4). S. aureus SCVs are always characterized by reduced pigment and haemolysis [22,140]. Moreover, most of the SCVs display other features, containing the repressed tricarboxylic acid cycle (TCA) cycle, the improved glycolysis, and the depressed global regulator factor AgrA, which eventually leads to reduced virulence and strengthens the persistent infections of SCVs [138,139].

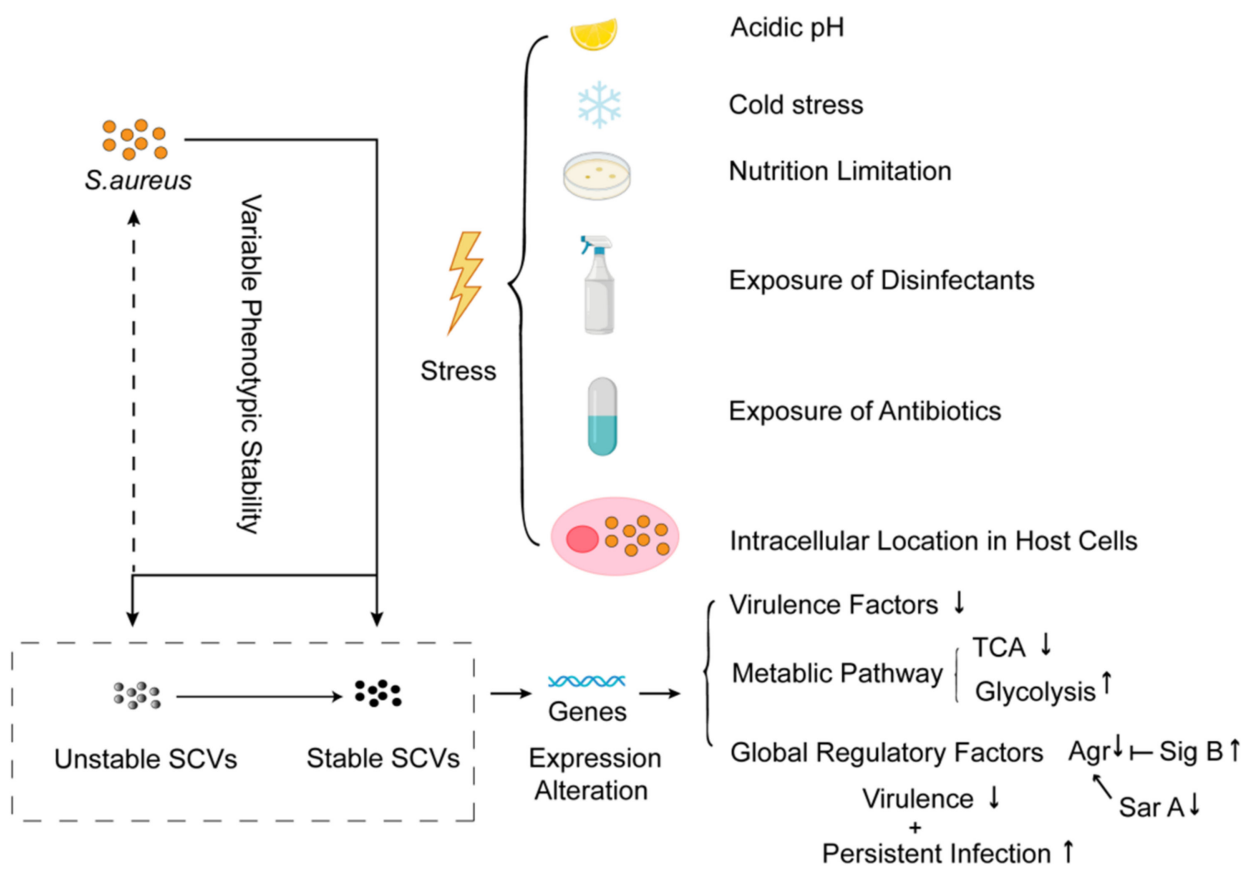

Figure 4. Formation and characteristics of S. aureus SCVs.

\subsubsection{Global Regulation of SCVs Formation}

Unlike the global regulation of $S$. aureus biofilm, the counterpart of SCVs demonstrates a trend with a repressed agr system. In detail, the depressed agr system in SCVs is a combination of increased negative regulators (e.g., SigB), decreased positive regulators (e.g., SarA), or the degraded function of RNA degrasome on the AgrA effector RNAIII [138,141-143]. As many of toxins are controlled by RNAIII, its downregulation leads to the persistent infection of SCVs without elimination by the host immune systems [144]. It is accepted that the persistent infections of S. aureus are strongly associated with the decrease or loss of essential virulence factors regulated by the agr system and RNAIII [138]. Meanwhile, the main features of SCVs, such as the increased cell-surface proteins and the repressed exotoxins, are related to the increased level of SigB [12], which also contributes to the persistent infections. It was demonstrated that $S$. aureus with a mutation in SigB lost the ability to transform into the SCV phenotype and could be removed by the host immune response $[100,145]$. What is more, SigB can regulate another global 
regulator, SarA, which increases the expression level of hemolysins and FnbA/FnbB in an agr-dependent/independent way $[146,147]$.

\subsubsection{Drug-Resistance Mechanisms Induced by SCVs}

Similar to the effects of biofilm, during the cause of infection, the SCVs also provide a safeguard from handicap, including the host immune system and antibiotic therapy. During infection, pathogens can usually stimulate the host immune response by reorganization between bacterial-specific antigens and PAMPs of the host cells [148]. However, compared to the wild S. aureus, SCVs with the dormant state tend to induce more attenuated host immune response during the infection of host cells, reflected by decreased chemokine and adhesion molecules [22,144], and eliminate effects of antimicrobial peptides inside the host's innate immune system $[149,150]$. Consequently, escaping from the severe host response, SCVs can function as a reservoir for high invasion and persistent infection inside the host cells [139]. What is more, it is possible for some intracellular-located SCVs to revert to the parental wild-type phenotype in a nutritionally rich environment or without selective pressure, called unstable SCVs, thus resulting in a dynamic S. aureus population $[8,151]$.

Moreover, SCVs can also lead to the disabled defense of the hosts' innate immune systems by altering the host metabolism, such as glycolysis, which is related to some critical immunologic functions [152]. In detail, SCVs often contain inactivating mutations in genes associated with the generation of the terminal electron transport chain components, haeme and menaquinone [153]. It was reported that both wild-type S. aureus and $\Delta$ hemB SCV (carrying a mutation in the hemin biosynthetic pathway) could promote glycolysis in host cells with the accumulation of mitochondrial reactive oxygen species (ROS) to induce caspase-independent host cell necroptosis without elimination of the microbial cells [153] (Figure 5). However, to maintain glycolysis, the $\triangle$ hemB SCV induced the expression of gene fumC encoding an enzyme to degrade a host glycolysis inhibitor fumarate, resulting in the inactivation of the epigenetic changes connected with trained immunity during secondary S. aureus infection of the host $[153,154]$, with effective increase pathogenicity of $\triangle$ hemB SCV [153].

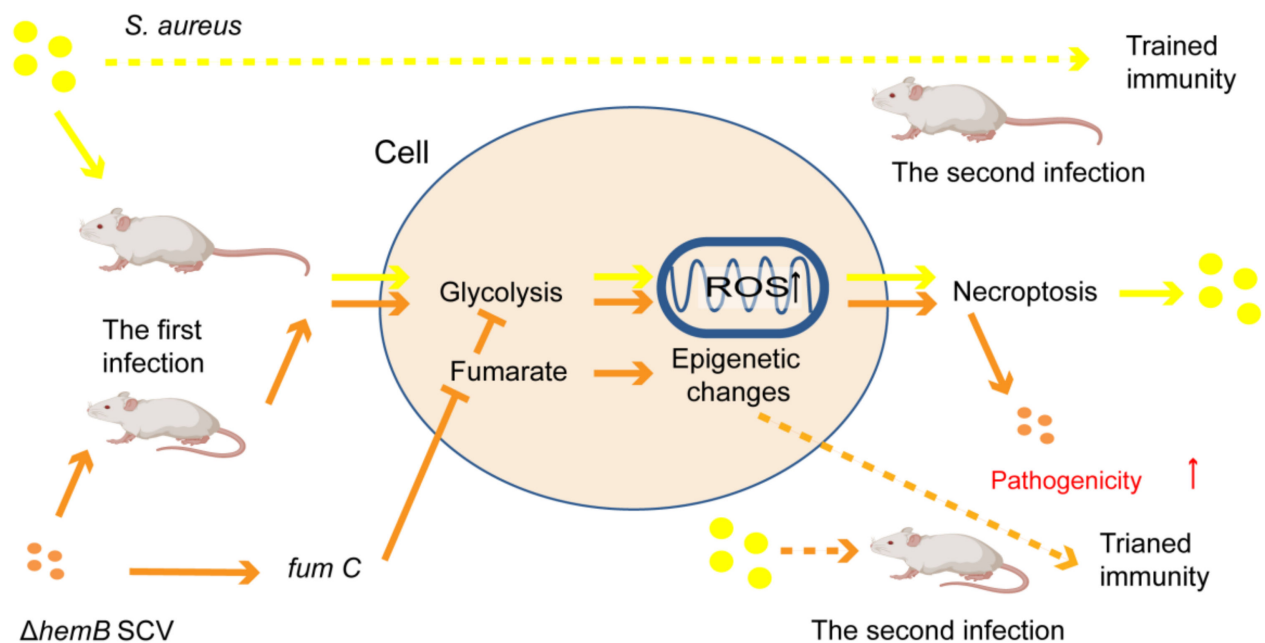

Figure 5. Effects of S. aureus $\triangle$ hemB SCV infection to mice. This figure was drawn according to the report of Lung et al. [153].

Due to the fact that SCVs possess those special features, including depressed metabolism, slow proliferation, and drug-resistance, there exist limited therapies to clinically combat SCVs [139]. Several studies have proved that $S$. aureus SCVs display an elevated antibiotic tolerance, which is independent of the accumulation of resistance genes $[8,155]$. Infections arising from dormant sub-population of bacteria with special metabolism and growth states will induce phenotypic tolerance of antibiotics. As an example, there are menadione- and 
haemin-auxotroph SCVs, which are typical types of SCVs induced by aminoglycosides antibiotics [7]. Generally, menadione and haemin are essential for the biosynthesis of cytochromes and menaquinone in the electron transport system, which contributes to the production of ATP [156]. The generation of ATP is demanded for forming normal colonies by facilitating cell wall biosynthesis, pigmentation, and membrane potential, which can promote the uptake of antibiotics, such as aminoglycosides $[157,158]$. Therefore, decreased ATP in the menadione- and haemin-auxotroph SCVs leads to the increased resistance of cell wall-specific drugs and limited uptake of antibiotics that need large membrane electrochemical gradients [159]. In addition, bacteria with decreased ATP will contribute to growth dormancy and less active antibiotic targets, followed by less damage under exposure to antibiotics, which accounts for the increasing drug tolerance [7]. Finally, host cells provide a shelter for SCVs to block the uptake of drugs with limited ability to cross the eukaryotic membranes [160].

\section{Conclusions and Future Recommendations}

Compared to most of the other reviews revealing the classical acquired drug resistance caused by the accumulation of the resistant genes, this review provides some new insights of $S$. aureus drug resistance from aspects of alternative phenotypes, including biofilm and SCVs, innovatively. Herein, we focus on the natural potential of $S$. aureus drug resistance.

Overall, accompanied by the usage of antibiotics, the development of the DR/MDR continues. However, it is complicated to understand the resistance of pathogens. To date, many studies have revealed the mechanisms of drug resistance. To take $S$. aureus as a resistant pathogen example, the acquired DR/MDR results from the accumulation of resistant genes or the altered physical or metabolic states of the special alternative phenotypes, biofilm and SCVs. The awareness of the public of those phenotypes is growing, along with increased studies about biofilm and SCVs in different fields. Despite the distinct forming reasons of SCVs and biofilm, the two lifestyles share similarities in certain features, such as the limited metabolism and growth, partial global regulation changes, and gene expression levels related to the extracellular surface components and virulence factors.

Both biofilm and SCVs are characterized by persistent infections, and growing resistance to antibiotics and antimicrobial agents, causing a severe burden on human health care. Consequently, the treatment of infections related to $S$. aureus alternative phenotypes is still a complicated challenge. With the development of biofilm research, there are many anti-biofilm agents that can inhibit the cycle of biofilm by penetrating the cell membrane of living pathogens, or block the development of biofilm through targeted disturbing of certain actions of QS systems. All those anti-biofilm agents can be classified as traditional natural active agents [161] and synthetic analogue anti-biofilm agents based on the biological and computational technology [162]. Furthermore, the increasing development of nano-materials also contributes to the abundance of the anti-biofilm agents that have shown great potential as promising bactericidal agents by physically destroying the bacteria cell membranes and further restraining the development of drug-resistant bacteria [163]. However, the development of anti-SCVs agents is comparatively underdeveloped. Until now, there have been few effective anti-SCVs agents found.

From the clinical perspective, we should pay more attention to chronic or persistent infections caused by biofilm or SCVs, due to their relapsing nature. Moreover, numerous studies are still in need of exploration to deal with the antibiotic resistance of $S$. aureus from the angle of the resistant phenotype-relevant regulatory pathways in certain infections. In short, this review provides a summary of the relationship between the alternative phenotypes and their native resistance mechanisms of antibiotics, which may help further investigations to combat the resistant pathogen in infections caused by the DR and MDR pathogen.

Author Contributions: H.G. wrote the review; Y.T. and J.C. edited the figures; Z.A. and Z.L. corrected grammatical errors; J.W. and Y.Z. corrected typing errors of the manuscript; D.S. reviewed the 
manuscript; R.Z. guided the article. All authors have read and agreed to the published version of the manuscript.

Funding: This work was funded by the National Key Research and Development Program of China (project No. 2018YFD0500600) and the National Natural Science Foundation of China (NSFC, 31572442).

Institutional Review Board Statement: Not applicable.

Informed Consent Statement: Not applicable.

Data Availability Statement: Not applicable.

Conflicts of Interest: The authors declare no conflict of interest.

\section{References}

1. Lekshmi, M.; Ammini, P.; Kumar, S.; Varela, M.F. The Food Production Environment and the Development of Antimicrobial Resistance in Human Pathogens of Animal Origin. Microorganisms 2017, 5, 11. [CrossRef] [PubMed]

2. $\quad$ Price, N.; Klein, J.L. Infectious Diseases; Oxford University Press (OUP): Oxford, UK, 2016.

3. Zohra, T.; Numan, M.; Ikram, A.; Salman, M.; Khan, T.; Din, M.; Salman, M.; Farooq, A.; Amir, A.; Ali, M. Cracking the Challenge of Antimicrobial Drug Resistance with CRISPR/Cas9, Nanotechnology and other Strategies in ESKAPE Pathogens. Microorganisms 2021, 9, 954. [CrossRef]

4. Levy, S.B.; Marshall, B. Antibacterial resistance worldwide: Causes, challenges and responses. Nat. Med. 2004, 10, S122-S129. [CrossRef] [PubMed]

5. Rice, L.B. Progress and Challenges in Implementing the Research on ESKAPE Pathogens. Infect. Control Hosp. Epidemiol. 2010, 31, S7-S10. [CrossRef]

6. Kahl, B.C.; Becker, K.; Loeffler, B. Clinical Significance and Pathogenesis of Staphylococcal Small Colony Variants in Persis-tent Infections. Clin. Microbiol. Rev. 2016, 29, 401-427. [CrossRef] [PubMed]

7. Bui, L.M.; Conlon, B.P.; Kidd, S.P. Antibiotic tolerance and the alternative lifestyles of Staphylococcus aureus. Essays Biochem. 2017, 61,71-79. [CrossRef] [PubMed]

8. Edwards, A.M. Phenotype Switching Is a Natural Consequence of Staphylococcus aureus Replication. J. Bacteriol. 2012, 194, 5404-5412. [CrossRef] [PubMed]

9. Boles, B.R.; Thoendel, M.; Singh, P.K. Self-generated diversity produces "insurance effects" in biofilm communities. Proc. Natl. Acad. Sci. USA 2004, 101, 16630-16635. [CrossRef]

10. Donlan, R.M.; Costerton, J.W. Biofilms: Survival Mechanisms of Clinically Relevant Microorganisms. Clin. Microbiol. Rev. 2002, 15, 167-193. [CrossRef]

11. Tuchscherr, L.; Geraci, J.; Löffler, B. Staphylococcus aureus Regulator Sigma B is Important to Develop Chronic Infections in Hematogenous Murine Osteomyelitis Model. Pathogens 2017, 6, 31. [CrossRef]

12. Tuchscherr, L.; Loeffler, B. Staphylococcus aureus Dynamically Adapts Global Regulators and Virulence Factor Expression in the Course from Acute to Chronic Infection. Curr. Genet. 2016, 62, 15-17. [CrossRef]

13. Tan, N.C.; Cooksley, C.M.; Roscioli, E.; Drilling, A.J.; Douglas, R.; Wormald, P.; Vreugde, S. Small-Colony Variants and Phenotype Switching of Intracellular Staphylococcus aureus in Chronic Rhinosinusitis. Allergy 2014, 69, 1364-1371. [CrossRef]

14. Mbbs, B.S.P.; Cooksley, C.M.; Ramezanpour, M.; Vediappan, R.S.; Bassiouni, A.; Wormald, P.J.; Psaltis, A.J.; Vreugde, S. Staphylococcus aureus biofilm exoproteins are cytotoxic to human nasal epithelial barrier in chronic rhinosinusitis. Int. Forum Allergy Rhinol. 2020, 10, 871-883. [CrossRef]

15. Xiao, N.; Yang, J.; Duan, N.; Lu, B.; Wang, L. Community-Associated Staphylococcus aureus PVL ${ }^{+}$ST22 predominates in skin and soft tissue infections in Beijing, China. Infect. Drug Resist. 2019, 12, 2495-2503. [CrossRef]

16. Besier, S.; Zander, J.; Siegel, E.; Saum, S.H.; Hunfeld, K.-P.; Ehrhart, A.; Brade, V.; Wichelhaus, T.A. Thymidine-Dependent Staphylococcus aureus Small-Colony Variants: Human Pathogens That Are Relevant Not Only in Cases of Cystic Fibrosis Lung Disease. J. Clin. Microbiol. 2008, 46, 3829-3832. [CrossRef]

17. Bates, D.M.; von Eiff, C.; McNamara, P.J.; Peters, G.; Yeaman, M.R.; Bayer, A.S.; Proctor, R.A. Staphylococcus aureus men D and hemB Mutants are as Infective as the Parent Strains, but the Menadione Biosynthetic Mutant Persists within the Kidney. J. Infect. Dis. 2003, 187, 1654-1661. [CrossRef]

18. Herrmann, M. Antimicrobial Effects Promoting Biofilm Formation and Persistent Disease: The Role of a DNA-Binding Regu-lator, SarA, in Staphylococcal endocarditis. J. Infect. Dis. 2014, 209, 1153-1155. [CrossRef]

19. Tuchscherr, L.; Pöllath, C.; Siegmund, A.; Deinhardt-Emmer, S.; Hoerr, V.; Svensson, C.-M.; Figge, M.T.; Monecke, S.; Löffler, B. Clinical, S. aureus Isolates Vary in Their Virulence to Promote Adaptation to the Host. Toxins 2019, 11, 135. [CrossRef]

20. Rom, J.S.; Beenken, K.E.; Ramirez, A.M.; Walker, C.M.; Echols, E.J.; Smeltzer, M.S. Limiting protease production plays a key role in the pathogenesis of the divergent clinical isolates of Staphylococcus aureus LAC and UAMS-1. Virulence 2021, 12, 584-600. [CrossRef] 
21. Spanu, T.; Romano, L.; D’Inzeo, T.; Masucci, L.; Albanese, A.; Papacci, F.; Marchese, E.; Sanguinetti, M.; Fadda, G. Recurrent Ventriculoperitoneal Shunt Infection Caused by Small-Colony Variants of Staphylococcus aureus. Clin. Infect. Dis. 2005, 41, e48-e52. [CrossRef]

22. Proctor, R.A.; von Eiff, C.; Kahl, B.C.; Becker, K.; McNamara, P.; Herrmann, M.; Peters, G. Small Colony Variants: A Patho-genic Form of Bacteria that Facilitates Persistent and Recurrent Infections. Nat. Rev. Microbiol. 2006, 4, 295-305. [CrossRef] [PubMed]

23. Huang, Q.; Xie, Y.; Yang, Z.; Cheng, D.; He, L.; Wang, H.; Liu, Q.; Li, M. The cytoplasmic loops of AgrC contribute to the quorum-sensing activity of Staphylococcus aureus. J. Microbiol. 2021, 59, 92-100. [CrossRef] [PubMed]

24. Cong, Y.; Yang, S.; Rao, X. Vancomycin resistant Staphylococcus aureus infections: A review of case updating and clinical features. J. Adv. Res. 2020, 21, 169-176. [CrossRef] [PubMed]

25. Chambers, H.F.; DeLeo, F.R. Waves of resistance: Staphylococcus aureus in the antibiotic era. Nat. Rev. Microbiol. 2009, 7, 629-641. [CrossRef]

26. Kirby, W.M.M. Extraction of a Highly Potent Penicillin Inactivator from Penicillin Resistant Staphylococci. Science 1944, 99, 452-453. [CrossRef]

27. Rountree, P.M.; Freeman, B.M. Infections caused by a particular phage type of Staphylococcus aureus. Med. J. Aust. 1955, 42, 157-161. [CrossRef]

28. Barber, M. Methicillin-Resistant Staphylococci. J. Clin. Pathol. 1961, 14, 385-393. [CrossRef]

29. Jevons, M.P.; Rolinson, G.N.; Knox, R. Celbenin-Resistant Staphylococci. Brit. Med. J. 1961, 2, 939. [CrossRef]

30. Weigel, L.M.; Clewell, D.B.; Gill, S.R.; Clark, N.C.; McDougal, L.K.; Flannagan, S.E.; Kolonay, J.F.; Shetty, J.; Killgore, G.E.; Tenover, F.C. Genetic Analysis of a High-Level Vancomycin-Resistant Isolate of Staphylococcus aureus. Science 2003, 302, $1569-1571$. [CrossRef]

31. Dunn, S.J.; Connor, C.; McNally, A. The Evolution and Transmission of Multi-Drug Resistant Escherichia coil and Klebsiella Pneumoniae: The Complexity of Clones and Plasmids. Curr. Opin. Microbiol. 2019, 51, 51-56. [CrossRef]

32. McInnes, R.S.; McCallum, G.E.; Lamberte, L.E.; van Schaik, W. Horizontal Transfer of Antibiotic Resistance Genes in the Human Gut Microbiome. Curr. Opin. Microbiol. 2020, 53, 35-43. [CrossRef]

33. Munk, P.; Knudsen, B.E.; Lukjancenko, O.; Duarte, A.S.R.; Van Gompel, L.; Luiken, R.E.C.; Smit, L.A.M.; Schmitt, H.; Garcia, A.D.; Hansen, R.B.; et al. Abundance and diversity of the faecal resistome in slaughter pigs and broilers in nine European countries. Nat. Microbiol. 2018, 3, 898-908. [CrossRef]

34. Sun, J.; Liao, X.; Souza, D.A.W.; Boolchandani, M.; Li, S.; Cheng, K.; Luis Martínez, J.; Li, L.; Feng, Y.; Fang, L.; et al. Environmental Remodeling of Human Gut Microbiota and Antibiotic Resistome in Livestock Farms. Nat. Commun. 2020, 11, 1427. [CrossRef]

35. Danner, M.C.; Robertson, A.; Behrends, V.; Reiss, J. Antibiotic pollution in surface fresh waters: Occurrence and effects. Sci. Total Environ. 2019, 664, 793-804. [CrossRef] [PubMed]

36. Naskar, A.; Kim, K.-S. Nanomaterials as Delivery Vehicles and Components of New Strategies to Combat Bacterial Infections: Advantages and Limitations. Microorganisms 2019, 7, 356. [CrossRef]

37. Kumar, V.A.; Khan, S. Defining multidrug resistance in Gram-negative bacilli. Indian J. Med. Res. 2015, 141, 491-492. [CrossRef]

38. Cassini, A.; Hogberg, L.D.; Plachouras, D.; Quattrocchi, A.; Hoxha, A.; Simonsen, G.S.; Colomb-Cotinat, M.; Kretzschmar, M.E.; Devleesschauwer, B.; Cecchini, M.; et al. At-tributable Deaths and Disability-Adjusted Life-Years Caused by Infections with Antibiotic-Resistant Bacteria in the EU and the European Economic Area in 2015: A Population-Level Modelling Analysis. Lancet Infect. Dis. 2019, 19, 56-66. [CrossRef]

39. Stewardson, A.; Marimuthu, K.; Sengupta, S.; Allignol, A.; El-Bouseary, M.; Carvalho, M.J.; Hassan, B.; Delgado-Ramirez, M.A.; Arora, A.; Bagga, R.; et al. Effect of Carbapenem Resistance on Outcomes of Bloodstream Infection Caused by Enterobacteriaceae in Low-Income and Middle-Income Countries (PANORAMA): A Multinational Prospective Co-hort Study. Lancet Infect. Dis. 2019, 19, 601-610. [CrossRef]

40. Gandra, S.; Tseng, K.K.; Arora, A.; Bhowmik, B.; Robinson, M.L.; Panigrahi, B.; Laxminarayan, R.; Klein, E.Y. The Mortality Burden of Multidrug-resistant Pathogens in India: A Retrospective, Observational Study. Clin. Infect. Dis. 2019, 69, 563-570. [CrossRef] [PubMed]

41. Wang, D.; Li, H.; Ma, X.; Tang, Y.; Tang, H.; Hu, X.; Liu, Z. Small RNA AvrA Regulates IscR to Increase the Stress Tolerances in SmpB Deficiency of Aeromonas veronii. Front Cell Infect Mi. 2019, 9, 142. [CrossRef] [PubMed]

42. Liu, Q.Y.; Ye, Y. A Study on Mining Bibliographic Records by Designed Software SATI: Case Study on Library and Information Science. J. Inf. Resour. Manag. 2012, 2, 50-58.

43. Lee, J.; Zilm, P.S.; Kidd, S.P. Novel Research Models for Staphylococcus aureus Small Colony Variants (SCV) Development: Co-pathogenesis and Growth Rate. Front. Microbiol. 2020, 11, 321. [CrossRef]

44. Tong, S.Y.C.; Davis, J.S.; Eichenberger, E.; Holland, T.L.; Fowler, V.G., Jr. Staphylococcus aureus Infections: Epidemiology, Pathophysiology, Clinical Manifestations, and Management. Clin. Microbiol. Rev. 2015, 28, 603-661. [CrossRef]

45. Fraunholz, M.; Sinha, B. Intracellular Staphylococcus aureus: Live-in and let die. Front. Cell. Infect. Microbiol. 2012, 2, 43. [CrossRef]

46. Strobel, M.; Pförtner, H.; Tuchscherr, L.; Völker, U.; Schmidt, F.; Kramko, N.; Schnittler, H.-J.; Fraunholz, M.; Löffler, B.; Peters, G.; et al. Post-invasion events after infection with Staphylococcus aureus are strongly dependent on both the host cell type and the infecting S. aureus strain. Clin. Microbiol. Infect. 2016, 22, 799-809. [CrossRef]

47. Häffner, N.; Bär, J.; Haunreiter, V.D.; Shambat, S.M.; Seidl, K.; Crosby, H.A.; Horswill, A.R.; Zinkernagel, A.S. Intracellular Environment and agr System Affect Colony Size Heterogeneity of Staphylococcus aureus. Front. Microbiol. 2020, 11, 1415. [CrossRef] 
48. Balaban, N.Q.; Merrin, J.; Chait, R.; Kowalik, L.; Leibler, S. Bacterial Persistence as a Phenotypic Switch. Science 2004, 305, 1622-1625. [CrossRef]

49. Wood, T.; Knabel, S.J.; Kwan, B.W. Bacterial Persister Cell Formation and Dormancy. Appl. Environ. Microbiol. 2013, 79, 7116-7121. [CrossRef]

50. Keren, I.; Kaldalu, N.; Spoering, A.; Wang, Y.; Lewis, K. Persister cells and tolerance to antimicrobials. FEMS Microbiol. Lett. 2004, 230, 13-18. [CrossRef]

51. Singh, R.; Ray, P.; Das, A.; Sharma, M. Role of persisters and small-colony variants in antibiotic resistance of planktonic and biofilm-associated Staphylococcus aureus: An in vitro study. J. Med. Microbiol. 2009, 58, 1067-1073. [CrossRef]

52. Chen, L.; Wen, Y. The role of bacterial biofilm in persistent infections and control strategies. Int. J. Oral Sci. 2011, 3, 66-73. [CrossRef] [PubMed]

53. Craft, K.M.; Nguyen, J.M.; Berg, L.J.; Townsend, S.D. Methicillin-Resistant Staphylococcus aureus (MRSA): Antibiotic-Resistance and the Biofilm Phenotype. Medchemcomm 2019, 1, 1231-1241. [CrossRef] [PubMed]

54. Schilcher, K.; Horswill, A.R. Staphylococcal Biofilm Development: Structure, Regulation, and Treatment Strategies. Microbiol. Mol. Biol. Rev. 2020, 84, e00026-19. [CrossRef]

55. Landini, P.; Antoniani, D.; Burgess, J.G.; Nijland, R. Molecular Mechanisms of Compounds Affecting Bacterial Biofilm For-mation and Dispersal. Appl. Microbiol. Biot. 2010, 86, 813-823. [CrossRef]

56. Kohler, C.; Von Eiff, C.; Liebeke, M.; McNamara, P.J.; Lalk, M.; Proctor, R.A.; Hecker, M.; Engelmann, S. A Defect in Menadione Biosynthesis Induces Global Changes in Gene Expression in Staphylococcus aureus. J. Bacteriol. 2008, 190, 6351-6364. [CrossRef]

57. Idrees, M.; Sawant, S.; Karodia, N.; Rahman, A. Staphylococcus aureus Biofilm: Morphology, Genetics, Pathogenesis and Treatment Strategies. Int. J. Environ. Res. Public Health 2021, 18, 7602. [CrossRef]

58. Reffuveille, F.; Josse, J.; Vallé, Q.; Gangloff, C.M.; Gangloff, S.C. Staphylococcus aureus Biofilms and Their Impact on the Medical Field. In The Rise of Virulence and Antibiotic Resistance in Staphylococcus aureus; InTech: Rijeka, Croatia, 2017 ; p. 187.

59. Nguyen, H.T.T.; Nguyen, T.H.; Otto, M. The Staphylococcal Exopolysaccharide PIA-Biosynthesis and Role in Biofilm Formation, Colonization, and Infection. Comput. Struct. Biotec. 2020, 18, 3324-3334. [CrossRef]

60. Corrigan, R.; Rigby, D.; Handley, P.; Foster, T.J. The role of Staphylococcus aureus surface protein SasG in adherence and biofilm formation. Microbiology 2007, 153, 2435-2446. [CrossRef]

61. Hauck, C.R.; Ohlsen, K. Sticky Connections: Extracellular Matrix Protein Recognition and Integrin-Mediated Cellular Invasion by Staphylococcus aureus Christof R Hauck and Knut Ohlsen. Curr. Opin. Microbiol. 2006, 9, 5-11. [CrossRef]

62. Foster, T.J.; Geoghegan, J.A.; Ganesh, V.K.; Höök, M. Adhesion, invasion and evasion: The many functions of the surface proteins of Staphylococcus aureus. Nat. Rev. Microbiol. 2014, 12, 49-62. [CrossRef]

63. Idrees, M.; Mohammad, A.R.; Karodia, N.; Rahman, A. Multimodal Role of Amino Acids in Microbial Control and Drug Development. Antibiotics 2020, 9, 330. [CrossRef]

64. Taglialegna, A.; Lasa, I.; Valle, J. Amyloid Structures as Biofilm Matrix Scaffolds. J. Bacteriol. 2016, 198, 2579-2588. [CrossRef] [PubMed]

65. Miao, J.; Lin, S.; Soteyome, T.; Peters, B.M.; Li, Y.; Chen, H.; Su, J.; Li, L.; Li, B.; Xu, Z.; et al. Biofilm Formation of Staphylococcus aureus under Food Heat Processing Conditions: First Report on CML Production within Biofilm. Sci. Rep. 2019, 9, 1312. [CrossRef] [PubMed]

66. Kong, K.-F.; Vuong, C.; Otto, M. Staphylococcus quorum sensing in biofilm formation and infection. Int. J. Med. Microbiol. 2006, 296, 133-139. [CrossRef]

67. Lu, L.; Hu, W.; Tian, Z.; Yuan, D.; Yi, G.; Zhou, Y.; Cheng, Q.; Zhu, J.; Li, M. Developing Natural Products as Potential Anti-Biofilm Agents. Chin. Med. UK 2019, 14, 11. [CrossRef]

68. Dunman, P.M.; Murphy, E.; Haney, S.; Palacios, D.; Tucker-Kellogg, G.; Wu, S.; Brown, E.L.; Zagursky, R.J.; Shlaes, D.; Projan, S.J. Transcription Profiling-Based Identification of Staphylococcus aureus Genes Regulated by the agr and/or sarA Loci. J. Bacteriol. 2001, 183, 7341-7353. [CrossRef]

69. Harraghy, N.; Kerdudou, S.; Herrmann, M. Quorum-sensing systems in Staphylococci as therapeutic targets. Anal. Bioanal. Chem. 2006, 387, 437-444. [CrossRef]

70. Gordon, C.P.; Olson, S.D.; Lister, J.L.; Kavanaugh, J.S.; Horswill, A.R. Truncated Autoinducing Peptides as Antagonists of Staphylococcus lugdunensis Quorum Sensing. J. Med. Chem. 2016, 59, 8879-8888. [CrossRef]

71. Novick, R.P.; Ross, H.F.; Projan, S.J.; Kornblum, J.; Kreiswirth, B.; Moghazeh, S. Synthesis of Staphylococcal Virulence Factors is Controlled by a Regulatory RNA Molecule. Embo J. 1993, 12, 3967-3975. [CrossRef]

72. Cheung, G.Y.C.; Wang, R.; Khan, B.A.; Sturdevant, D.E.; Otto, M. Role of the Accessory Gene Regulator Agr in CommunityAssociated Methicillin-Resistant Staphylococcus aureus Pathogenesis. Infect. Immun. 2011, 79, 1927-1935. [CrossRef]

73. Le, K.Y.; Villaruz, A.E.; Zheng, Y.; He, L.; Fisher, E.L.; Nguyen, T.H.; Ho, T.V.; Yeh, A.J.; Joo, H.-S.; Cheung, G.Y.; et al. Role of Phenol-Soluble Modulins in Staphylococcus epidermidis Biofilm Formation and Infection of Indwelling Medical Devices. J. Mol. Biol. 2019, 431, 3015-3027. [CrossRef]

74. Boles, B.R.; Horswill, A.R. Agr-Mediated Dispersal of Staphylococcus aureus Biofilms. PLoS Pathog. 2008, 4, e1000052. [CrossRef]

75. Lister, J.L.; Horswill, A.R. Staphylococcus aureus biofilms: Recent developments in biofilm dispersal. Front. Cell. Infect. Microbiol. 2014, 4, 178. [CrossRef] 
76. Giraudo, A.T.; Calzolari, A.; Cataldi, A.A.; Bogni, C.; Nagel, R. The Sae Locus of Staphylococcus aureus Encodes a Two-Component Regulatory System. Fems Microbiol. Lett. 1999, 180, 117. [PubMed]

77. Olson, M.E.; Nygaard, T.K.; Ackermann, L.; Watkins, R.L.; Zurek, O.W.; Pallister, K.B.; Griffith, S.; Kiedrowski, M.R.; Flack, C.E.; Kavanaugh, J.S.; et al. Staphylococcus aureus Nuclease is an SaeRS-Dependent Virulence Factor. Infect. Immun. 2013, 81, 1316-1324. [CrossRef] [PubMed]

78. Xiong, Y.Q.; Willard, J.; Yeaman, M.R.; Cheung, A.L.; Bayer, A.S. Regulation of Staphylococcus aureus Alpha-Toxin Gene (Hla) Expression by Agr, sarA, and Sae in vitro and in Experimental Infective Endocarditis. J. Infect. Dis. 2006, 194, 1267-1275. [CrossRef] [PubMed]

79. Liang, X.; Yu, C.; Sun, J.; Liu, H.; Landwehr, C.; Holmes, D.; Ji, Y. Inactivation of a Two-Component Signal Transduction System, SaeRS, Eliminates Adherence and Attenuates Virulence of Staphylococcus aureus. Infect. Immun. 2006, 74, 4655-4665. [CrossRef] [PubMed]

80. Rogasch, K.; Rühmling, V.; Pané-Farré, J.; Höper, D.; Weinberg, C.; Fuchs, S.; Schmudde, M.; Bröker, B.; Wolz, C.; Hecker, M.; et al. Influence of the Two-Component System SaeRS on Global Gene Expression in Two Different Staphylococcus aureus Strains. J. Bacteriol. 2006, 188, 7742-7758. [CrossRef]

81. Flack, C.E.; Zurek, O.W.; Meishery, D.D.; Pallister, K.B.; Malone, C.L.; Horswill, A.R.; Voyich, J.M. Differential regulation of staphylococcal virulence by the sensor kinase SaeS in response to neutrophil-derived stimuli. Proc. Natl. Acad. Sci. USA 2014, 111, E2037-E2045. [CrossRef]

82. Sadykov, M.R.; Bayles, K.W. The control of death and lysis in staphylococcal biofilms: A coordination of physiological signals. Curr. Opin. Microbiol. 2012, 15, 211-215. [CrossRef]

83. Rice, K.C.; Firek, B.A.; Nelson, J.B.; Yang, S.-J.; Patton, T.G.; Bayles, K.W. The Staphylococcus aureus cidAB Operon: Evaluation of Its Role in Regulation of Murein Hydrolase Activity and Penicillin Tolerance. J. Bacteriol. 2003, 185, 2635-2643. [CrossRef]

84. Groicher, K.H.; Firek, B.A.; Fujimoto, D.F.; Bayles, K.W. The Staphylococcus aureus lrgAB Operon Modulates Murein Hydro-lase Activity and Penicillin Tolerance. J. Bacteriol. 2000, 182, 1794-1801. [CrossRef]

85. Ranjit, D.K.; Endres, J.L.; Bayles, K.W. Staphylococcus aureus CidA and LrgA Proteins Exhibit Holin-Like Properties. J. Bacteriol. 2011, 193, 2468-2476. [CrossRef]

86. Brunskill, E.W.; Bayles, K.W. Identification and Molecular Characterization of a Putative Regulatory Locus that Affects Autolysis in Staphylococcus aureus. J. Bacteriol. 1996, 178, 611-618. [CrossRef]

87. Schmidt, K.A.; Manna, A.C.; Cheung, A.L. SarT influences sarS expression in Staphylococcus aureus. Infect. Immun. 2003, 71, 5139-5148. [CrossRef]

88. Heinrichs, J.H.; Bayer, M.G.; Cheung, A.L. Characterization of the sar locus and its interaction with agr in Staphylococcus aureus. J. Bacteriol. 1996, 178, 418-423. [CrossRef]

89. Zielinska, A.K.; Beenken, K.E.; Mrak, L.N.; Spencer, H.J.; Post, G.R.; Skinner, R.A.; Tackett, A.J.; Horswill, A.R.; Smeltzer, M.S. SarA-mediated Repression of Protease Production Plays a Key Role in the Pathogenesis of Staphylococcus aureus USA300 Isolates. Mol. Microbiol. 2012, 86, 1183-1196. [CrossRef]

90. McNamara, P.J.; Milligan-Monroe, K.C.; Khalili, S.; Proctor, R.A. Identification, Cloning, and Initial Characterization of rot, a Locus Encoding a Regulator of Virulence Factor Expression in Staphylococcus aureus. J. Bacteriol. 2000, 182, 3197-3203. [CrossRef]

91. Saïd-Salim, B.; Dunman, P.M.; McAleese, F.M.; Macapagal, D.; Murphy, E.; McNamara, P.J.; Arvidson, S.; Foster, T.J.; Projan, S.J.; Kreiswirth, B.N. Global Regulation of Staphylococcus aureus Genes by Rot. J. Bacteriol. 2003, 185, 610-619. [CrossRef]

92. Tuffs, S.W.; Herfst, C.A.; Baroja, M.L.; Podskalniy, V.A.; DeJong, E.N.; Coleman, C.E.M.; McCormick, J.K. Regulation of Toxic Shock Syndrome Toxin-1 by the Accessory Gene Regulator in Staphylococcus aureus is Mediated by the Repressor of Toxins. Mol. Microbiol. 2019, 112, 1163-1177. [CrossRef]

93. Geisinger, E.; Adhikari, R.P.; Jin, R.; Ross, H.F.; Novick, R.P. Inhibition of rot translation by RNAIII, a key feature of agr function. Mol. Microbiol. 2006, 61, 1038-1048. [CrossRef]

94. Boisset, S.; Geissmann, T.; Huntzinger, E.; Fechter, P.; Bendridi, N.; Possedko, M.; Chevalier, C.; Helfer, A.C.; Benito, Y.; Jacquier A.; et al. Staphylococcus aureus RNAIII coordinately represses the synthesis of virulence factors and the transcription regulator Rot by an antisense mechanism. Genes Dev. 2007, 21, 1353-1366. [CrossRef]

95. Crosby, H.; Schlievert, P.; Merriman, J.A.; King, J.M.; Salgado-Pabon, W.; Horswill, A.R. The Staphylococcus aureus Global Regulator MgrA Modulates Clumping and Virulence by Controlling Surface Protein Expression. PLoS Pathog. 2016, 12, e1005604. [CrossRef]

96. Pane-Farre, J.; Jonas, B.; Foerstner, K.; Engelmann, S.; Hecker, M. The sigma(B) Regulon in Staphylococcus aureus and its Regulation. Int. J. Med. Microbiol. 2006, 296, 237-258. [CrossRef] [PubMed]

97. Atwood, D.N.; Loughran, A.J.; Courtney, A.P.; Anthony, A.C.; Meeker, D.G.; Spencer, H.J.; Gupta, R.K.; Lee, C.Y.; Beenken, K.E.; Smeltzer, M.S. Comparative impact of diverse regulatory loci on Staphylococcus aureus biofilm formation. MicrobiologyOpen 2015, 4, 436-451. [CrossRef] [PubMed]

98. Kullik, I.; Giachino, P.; Fuchs, T. Deletion of the Alternative Sigma Factor sigma(B) in Staphylococcus aureus Reveals its Function as a Global Regulator of Virulence Genes. J. Bacteriol. 1998, 180, 4814-4820. [CrossRef] [PubMed]

99. Donegan, N.P.; Cheung, A.L. Regulation of the mazEF Toxin-Antitoxin Module in Staphylococcus aureus and Its Impact on sigB Expression. J. Bacteriol. 2009, 191, 2795-2805. [CrossRef] [PubMed]

100. Bischoff, M.; Dunman, P.; Kormanec, J.; Macapagal, D.; Murphy, E.; Mounts, W.; Berger-Bachi, B.; Projan, S. Microar-ray-Based Analysis of the Staphylococcus aureus sigma(B) Regulon. J. Bacteriol. 2004, 186, 4085-4099. [CrossRef] 
101. Nair, S.P.; Bischoff, M.; Senn, M.M.; Berger-Bachi, B. The sigma(B) Regulon Influences Internalization of Staphylococcus aureus by Osteoblasts. Infect. Immun. 2003, 71, 4167-4170. [CrossRef]

102. Bischoff, M.; Entenza, J.M.; Giachino, P. Influence of a Functional sigB Operon on the Global Regulators sar and agr in Staphylococcus aureus. J. Bacteriol. 2001, 183, 4079-4089. [CrossRef]

103. Horsburgh, M.J.; Aish, J.L.; White, I.J.; Shaw, L.; Lithgow, J.K.; Foster, S.J. Sigma(B) Modulates Virulence Determinant Expression and Stress Resistance: Characterization of a Functional rsbU Strain Derivedfrom Staphylococcus aureus 8325-4. J. Bacteriol. 2002, 184, 5457-5467. [CrossRef] [PubMed]

104. Geiger, T.; Goerke, C.; Mainiero, M.; Kraus, D.; Wolz, C. The Virulence Regulator Sae of Staphylococcus aureus: Promoter Activities and Response to Phagocytosis-Related Signals. J. Bacteriol. 2008, 190, 3419-3428. [CrossRef] [PubMed]

105. Stenz, L.; Francois, P.; Whiteson, K.; Wolz, C.; Linder, P.; Schrenzel, J. The CodY pleiotropic repressor controls virulence in gram-positive pathogens. FEMS Immunol. Med. Microbiol. 2011, 62, 123-139. [CrossRef] [PubMed]

106. Pohl, K.; Francois, P.; Stenz, L.; Schlink, F.; Geiger, T.; Herbert, S.; Goerke, C.; Schrenzel, J.; Wolz, C. CodY in Staphylococcus aureus: A Regulatory Link between Metabolism and Virulence Gene Expression. J. Bacteriol. 2009, 191, 2953-2963. [CrossRef]

107. Majerczyk, C.D.; Dunman, P.M.; Luong, T.T.; Lee, C.Y.; Sadykov, M.R.; Somerville, G.; Bodi, K.; Sonenshein, A.L. Direct Targets of CodY in Staphylococcus aureus. J. Bacteriol. 2010, 192, 2861-2877. [CrossRef]

108. Waters, N.R.; Samuels, D.J.; Behera, R.K.; Livny, J.; Rhee, K.Y.; Sadykov, M.R.; Brinsmade, S.R. A Spectrum of CodY Activities Drives Metabolic Reorganization and Virulence Gene Expression in Staphylococcus aureus. Mol. Microbiol. 2016, 101, 495-514. [CrossRef]

109. Majerczyk, C.D.; Sadykov, M.R.; Luong, T.T.; Lee, C.; Somerville, G.A.; Sonenshein, A.L. Staphylococcus aureus CodY Nega-tively Regulates Virulence Gene Expression. J. Bacteriol. 2008, 190, 2257-2265. [CrossRef]

110. Roy, R.; Tiwari, M.; Donelli, G.; Tiwari, V. Strategies for combating bacterial biofilms: A focus on anti-biofilm agents and their mechanisms of action. Virulence 2018, 9, 522-554. [CrossRef]

111. Otto, M. Staphylococcal Biofilms. Microbiol. Spectr. 2018, 6, 10. [CrossRef]

112. Verma, J.; Bag, S.; Saha, B.; Kumar, P.; Ghosh, T.S.; Dayal, M.; Senapati, T.; Mehra, S.; Dey, P.; Desigamani, A.; et al. Genomic plasticity associated with antimicrobial resistance inVibrio cholerae. Proc. Natl. Acad. Sci. USA 2019, 116, 6226-6231. [CrossRef]

113. Hoiby, N.; Johansen, H.K.; Moser, C.; Song, Z.J.; Ciofu, O.; Kharazmi, A. Pseudomonas aeruginosa and the in vitro and in vivo Biofilm Mode of Growth. Microbes Infect. 2001, 3, 23-35. [CrossRef]

114. Bassetti, M.; Vena, A.; Croxatto, A.; Righi, E.; Guery, B. How to manage Pseudomonas aeruginosa infections. Drugs Context 2018, 7, 212527. [CrossRef]

115. Cramton, S.E.; Gerke, C.; Schnell, N.F.; Nichols, W.W.; Gotz, F. The Intercellular Adhesion (Ica) Locus is Present in Staphylococcus aureus and is Required for Biofilm Formation. Infect. Immun. 1999, 67, 5427-5433. [CrossRef]

116. Gotz, F. Staphylococcus and Biofilms. Mol. Microbiol. 2002, 43, 1367-1378. [CrossRef]

117. Donlan, R.M. Role of Biofilms in Antimicrobial Resistance. Asaio J. 2000, 46, S47-S52. [CrossRef]

118. Ou, C.; Shang, D.; Yang, J.; Chen, B.; Chang, J.; Jin, F.; Shi, C. Prevalence of Multidrug-Resistant Staphylococcus aureus Isolates with Strong Biofilm Formation Ability Among Animal-Based Food in Shanghai. Food Control. 2020, 112, 107106. [CrossRef]

119. Costerton, J.W.; Stewart, P.S.; Greenberg, E.P. Bacterial Biofilms: A Common Cause of Persistent Infections. Science 1999, 284, 1318-1322. [CrossRef]

120. Bjarnsholt, T.; Jensen, P.O.; Fiandaca, M.J.; Pedersen, J.; Hansen, C.R.; Andersen, C.B.; Pressler, T.; Givskov, M.; Hoiby, N. Pseudomonas aeruginosa Biofilms in the Respiratory Tract of Cystic Fibrosis Patients. Pediatr. Pulm. 2009, 44, 547-558. [CrossRef]

121. Wu, H.; Moser, C.; Wang, H.-Z.; Høiby, N.; Song, Z.-J. Strategies for combating bacterial biofilm infections. Int. J. Oral Sci. 2015, 7, 1-7. [CrossRef]

122. Miyaue, S.; Suzuki, E.; Komiyama, Y.; Kondo, Y.; Morikawa, M.; Maeda, S. Bacterial Memory of Persisters: Bacterial Persister Cells Can Retain Their Phenotype for Days or Weeks After Withdrawal from Colony-Biofilm Culture. Front. Microbiol. 2018, 9 , 1396. [CrossRef]

123. Wood, T.K. Strategies for combating persister cell and biofilm infections. Microb. Biotechnol. 2017, 10, 1054-1056. [CrossRef] [PubMed]

124. Conlon, B.P.; Rowe, S.E.; Lewis, K. Persister Cells in Biofilm Associated Infections. In Advances in Experimental Medicine and Biology; Springer Science and Business Media LLC: Berlin/Heidelberg, Germany, 2014; Volume 831, pp. 1-9.

125. Anderl, J.N.; Zahller, J.; Roe, F.; Stewart, P.S. Role of Nutrient Limitation and Stationary-Phase Existence in Klebsiella Pneumoniae Biofilm Resistance to Ampicillin and Ciprofloxacin. Antimicrob. Agents Chemother. 2003, 47, 1251-1256. [CrossRef] [PubMed]

126. Brown, M.R.W.; Allison, D.G.; Gilbert, P. Resistance of bacterial biofilms to antibiotics a growth-rate related effect? J. Antimicrob. Chemother. 1988, 22, 777-780. [CrossRef] [PubMed]

127. Waters, E.; Rowe, S.E.; O'Gara, J.P.; Conlon, B.P. Convergence of Staphylococcus aureus Persister and Biofilm Research: Can Biofilms Be Defined as Communities of Adherent Persister Cells? PLoS Pathog. 2016, 12, e1006012. [CrossRef] [PubMed]

128. Ma, H.; Bryers, J.D. Non-invasive determination of conjugative transfer of plasmids bearing antibiotic-resistance genes in biofilm-bound bacteria: Effects of substrate loading and antibiotic selection. Appl. Microbiol. Biotechnol. 2012, 97, 317-328. [CrossRef] [PubMed]

129. Proctor, R.A.; Van Langevelde, P.; Kristjansson, M.; Maslow, J.N.; Arbeit, R.D. Persistent and Relapsing Infections Associated with Small-Colony Variants of Staphylococcus aureus. Clin. Infect. Dis. 1995, 20, 95-102. [CrossRef] 
130. Kim, N.-H.; Kang, Y.M.; Han, W.D.; Park, K.U.; Park, K.-H.; Yoo, J.I.; Lee, D.-G.; Park, C.; Song, K.-H.; Kim, E.S.; et al. Small-Colony Variants in Persistent and Recurrent Staphylococcus aureus Bacteremia. Microb. Drug Resist. 2016, 22, 538-544. [CrossRef]

131. Kussmann, M.; Karer, M.; Obermueller, M.; Schmidt, K.; Barousch, W.; Moser, D.; Nehr, M.; Ramharter, M.; Poeppl, W.; Makristathis, A.; et al. Emergence of a Dalbavancin Induced Glycopep-tide/Lipoglycopeptide Non-Susceptible Staphylococcus aureus During Treatment of a Cardiac Device-Related Endocarditis. Emerg. Microbes Infec. 2018, 7, 202. [CrossRef]

132. Schwerdt, M.; Neumann, C.; Schwartbeck, B.; Kampmeier, S.; Herzog, S.; Görlich, D.; Dübbers, A.; Große-Onnebrink, J.; Kessler, C.; Küster, P.; et al. Staphylococcus aureus in the airways of cystic fibrosis patients-A retrospective long-term study. Int. J. Med. Microbiol. 2018, 308, 631-639. [CrossRef]

133. VonEiff, C.; Bettin, D.; Proctor, R.A.; Rolauffs, B.; Lindner, N.; Winkelmann, W.; Peters, G. Recovery of Small Colony Variants of Staphylococcus aureus Following Gentamicin Bead Placement for Osteomyelitis. Clin. Infect. Dis. 1997, 25, 1250-1251. [CrossRef]

134. Besier, S.; Smaczny, C.; von Mallinckrodt, C.; Krahl, A.; Ackermann, H.; Brade, V.; Wichelhaus, T.A. Prevalence and Clinical Significance of Staphylococcus aureus Small-Colony Variants in Cystic Fibrosis Lung Disease. J. Clin. Microbiol. 2007, 45, 168-172. [CrossRef]

135. Kahl, B.C.; Belling, G.; Reichelt, R.; Herrmann, M.; Proctor, R.A.; Peters, G. Thymidine-Dependent Small-Colony Variants of Staphylococcus aureus Exhibit Gross Morphological and Ultrastructural Changes Consistent with Impaired Cell Separation. J. Clin. Microbiol. 2003, 41, 410-413. [CrossRef]

136. Kahl, B.; Herrmann, M.; Everding, A.S.; Koch, H.G.; Becker, K.; Harms, E.; Proctor, R.A.; Peters, G. Persistent Infection with Small Colony Variant Strains of Staphylococcus aureus in Patients with Cystic Fibrosis. J. Infect. Dis. 1998, 177, 1023-1029. [CrossRef]

137. Leimer, N.; Rachmühl, C.; Marques, M.P.; Bahlmann, A.S.; Furrer, A.; Eichenseher, F.; Seidl, K.; Matt, U.; Loessner, M.J.; Schuepbach, R.A.; et al. Nonstable Staphylococcus aureus Small-Colony Variants are Induced by Low pH and Sensitized to Antimicrobial Therapy by Phagolysosomal Alkalinization. J. Infect. Dis. 2016, 213, 305-313. [CrossRef]

138. Tuchscherr, L.; Loeffler, B.; Proctor, R.A. Persistence of Staphylococcus aureus: Multiple Metabolic Pathways Impact the Expression of Virulence Factors in Small-Colony Variants (SCVs). Front. Microbiol. 2020, 11, 1028. [CrossRef]

139. Kahl, B.C. Small colony variants (SCVs) of Staphylococcus aureus-A bacterial survival strategy. Infect. Genet. Evol. 2014, 21, 515-522. [CrossRef] [PubMed]

140. Sendi, P.; Proctor, R.A. Staphylococcus aureus as an intracellular pathogen: The role of small colony variants. Trends Microbiol. 2009, 17, 54-58. [CrossRef]

141. Proctor, R. Respiration and Small Colony Variants of Staphylococcus aureus. Microbiol. Spectr. 2019, 7, 22. [CrossRef]

142. Oun, S.; Redder, P.; Didier, J.-P.; François, P.; Corvaglia, A.-R.; Buttazzoni, E.; Giraud, C.; Girard, M.; Schrenzel, J.; Linder, P. The CshA DEAD-box RNA helicase is important for quorum sensing control in Staphylococcus aureus. RNA Biol. 2013, 10, 157-165. [CrossRef]

143. Roux, C.M.; DeMuth, J.P.; Dunman, P.M. Characterization of Components of the Staphylococcus aureus mRNA Degradosome Holoenzyme-Like Complex. J. Bacteriol. 2011, 193, 5520-5526. [CrossRef]

144. Tuchscherr, L.; Heitmann, V.; Hussain, M.; Viemann, D.; Roth, J.; von Eiff, C.; Peters, G.; Becker, K.; Loeffler, B. Staphylococcus aureus Small-Colony Variants are Adapted Phenotypes for Intracellular Persistence. J. Infect. Dis. 2010, 202, 1031-1040. [CrossRef] [PubMed]

145. Tuchscherr, L.; Bischoff, M.; Lattar, S.M.; Noto Llana, M.; Pförtner, H.; Niemann, S.; Geraci, J.; Van De Vyver, H.; Fraunholz, M.J.; Cheung, A.L.; et al. Sigma Factor SigB Is Crucial to Mediate Staphylococcus aureus Adaptation during Chronic Infections. PLoS Pathog. 2015, 11, e1004870. [CrossRef] [PubMed]

146. Deora, R.; Tseng, T.; Misra, T.K. Alternative transcription factor sigmaSB of Staphylococcus aureus: Characterization and role in transcription of the global regulatory locus sar. J. Bacteriol. 1997, 179, 6355-6359. [CrossRef] [PubMed]

147. Cheung, A.L.; Zhang, G. Global regulation of virulence determinants in Staphylococcus aureus by the SarA protein family. Front. Biosci. Landmark 2002, 7, D1825-D1842. [CrossRef] [PubMed]

148. Kim, H.M.; Park, B.S.; Kim, J.-I.; Kim, S.E.; Lee, J.; Oh, S.C.; Enkhbayar, P.; Matsushima, N.; Lee, H.; Yoo, O.J.; et al. Crystal Structure of the TLR4-MD-2 Complex with Bound Endotoxin Antagonist Eritoran. Cell 2007, 130, 906-917. [CrossRef] [PubMed]

149. Samuelsen, O.; Haukland, H.H.; Kahl, B.C.; von Eiff, C.; Proctor, R.A.; Ulvatne, H.; Sandvik, K.; Vorland, L.H. Staphylococcus aureus Small Colony Variants are Resistant to the Antimicrobial Peptide Lactoferricin B. J. Antimicrob. Chemoth. 2005, 56, 1126-1129. [CrossRef]

150. Werth, N.; Beerlage, C.; Rosenberger, C.; Yazdi, A.S.; Edelmann, M.; Amr, A.; Bernhardt, W.; Von Eiff, C.; Becker, K.; Schäfer, A.; et al. Activation of Hypoxia Inducible Factor 1 Is a General Phenomenon in Infections with Human Pathogens. PLoS ONE 2010, 5, e11576. [CrossRef]

151. Tuchscherr, L.; Medina, E.; Hussain, M.; Völker, W.; Heitmann, V.; Niemann, S.; Holzinger, D.; Roth, J.; Proctor, R.A.; Becker, K.; et al. Staphylococcus aureus phenotype switching: An effective bacterial strategy to escape host immune response and establish a chronic infection. EMBO Mol. Med. 2011, 3, 129-141. [CrossRef]

152. Arts, R.J.; Joosten, L.A.; Netea, M.G. Immunometabolic circuits in trained immunity. Semin. Immunol. 2016, 28, 425-430. [CrossRef]

153. Lung, T.W.F.; Monk, I.R.; Acker, K.P.; Mu, A.; Wang, N.; Riquelme, S.A.; Pires, S.; Noguera, L.P.; Dach, F.; Gabryszewski, S.J.; et al Staphylococcus aureus small colony variants impair host immunity by activating host cell glycolysis and inducing necroptosis. Nat. Microbiol. 2020, 5, 141-153. [CrossRef] 
154. Arts, R.J.W.; Novakovic, B.; ter Horst, R.; Carvalho, A.; Bekkering, S.; Lachmandas, E.; Rodrigues, F.; Silvestre, R.; Cheng, S.; Wang, S.; et al. Glutaminolysis and Fumarate Accumulation Integrate Immunometabolic and Epigenetic Programs in Trained Immunity. Cell Metab. 2016, 24, 807-819. [CrossRef]

155. Lechner, S.; Lewis, K.; Bertram, R. Staphylococcus aureus Persisters Tolerant to Bactericidal Antibiotics. J. Mol. Microbiol. Biotechnol. 2012, 22, 235-244. [CrossRef]

156. Proctor, R.; Vesga, O.; Otten, M.; Koo, S.-P.; Yeaman, M.; Sahl, H.-G.; Bayer, A. Staphylococcus aureus Small Colony Variants Cause Persistent and Resistant Infections. Chemotherapy 1996, 42, 47-52. [CrossRef]

157. Melter, O.; Radojevič, B. Small colony variants of Staphylococcus aureus-Review. Folia. Microbiol. 2010, 55, 548-558. [CrossRef]

158. Garcia, L.G.; Lemaire, S.; Kahl, B.C.; Becker, K.; Proctor, R.A.; Denis, O.; Tulkens, P.M.; Van Bambeke, F. Antibiotic activity against small-colony variants of Staphylococcus aureus: Review of in vitro, animal and clinical data. J. Antimicrob. Chemother. 2013, 68, 1455-1464. [CrossRef]

159. McNamara, P.J.; Proctor, A.R. Staphylococcus aureus small colony variants, electron transport and persistent infections. Int. J. Antimicrob. Agents 2000, 14, 117-122. [CrossRef]

160. Darouiche, O.R.; Hamill, R.J. Antibiotic penetration of and bactericidal activity within endothelial cells. Antimicrob. Agents Chemother. 1994, 38, 1059-1064. [CrossRef]

161. Mishra, R.; Panda, A.K.; De Mandal, S.; Shakeel, M.; Bisht, S.S.; Khan, J. Natural Anti-Biofilm Agents: Strategies to Control Biofilm-Forming Pathogens. Front. Microbiol. 2020, 11, 566325. [CrossRef]

162. An, A.Y.; Choi, K.-Y.G.; Baghela, A.S.; Hancock, R.E.W. An Overview of Biological and Computational Methods for Designing Mechanism-InforMed. Anti-biofilm Agents. Front. Microbiol. 2021, 12, 640787. [CrossRef]

163. Malaekeh-Nikouei, B.; Bazzaz, B.S.F.; Mirhadi, E.; Tajani, A.S.; Khameneh, B. The role of nanotechnology in combating biofilmbased antibiotic resistance. J. Drug Deliv. Sci. Technol. 2020, 60, 101880. [CrossRef] 